\title{
AIDS: The Role of Islamic Sexual Rules in Prevention
}

Dr. Abdulwahab A. Noorwali, Dr. Anwar A. R. Elawad

Jeddah, Saudi Arabia

DOI: http://dx.doi.org/10.5915/19-2-13047

\begin{abstract}
The spread of "Fähisha" that is adultery and homosexuality in a society, results in a high incidence of serious sexually-transmitted diseases. In addition, they may lead to the spread of new epidemic diseases such as AIDS. These facts have all been mentioned in a "Hadith" by Prophet Mohammad (PBUH):

"... Whenever adultery and homosexuality appear in a society and people make them public (and become acceptable), plague and other diseases which were previously not known to their predecessors will appear and spread among them..."

For prevention against these diseases, Islam has laid down clear measures; encouraging youth to get married and prohibiting the sexual practices of adultery and homosexuality.
\end{abstract}

Key words: $A I D S$, public health, sex, ethics.

In June and July 1981 the first cases of the Acquired Immunodeficiency Syndrome (AIDS) were reported in the U.S.A. as cases of Pneumocystis Carinii pneumonia in association with the rare skin malignancy, Kaposi's sarcoma. ${ }^{2}$ These early cases were identified in previously healthy active homosexual men in New York and Los Angeles. ${ }^{3}$ Soon a world-wide concern escalated as more cases were identified. Over the last four years more than six thousand cases of AIDS have been reported from all over the United States and other Western European Countries. About $71 \%$ of these cases were reported in young active homosexual men. ${ }^{4}$ Moreover AIDS cases have also been reported in women who were sexual partners of male patients with AIDS.

All of the epidemiologic data collected to date about this syndrome point to the important role of person-to-person transmission occuring mainly through sexual, and in particular homosexual, contact. This route of transmission could be very important since the majority $(71 \%)$ of patients reported are

From the Departments of Chemical Pathology, and Microbiology,

College of Medicine and Allied Sciences,

King Abdulaziz University

Reprint Requests: Dr. Abdulwahab A. Noorwali, Assistant Professor, Department of Chemical Pathology, College of Medicine and Allied Sciences,

King Abdulaziz University,

P.O. Box 6615, Jeddah,

Saudi Arabia young homosexuals, especially homosexuals with multiple sexual partners.

The world-wide concern and tension that has accompanied the spread of this syndrome has arisen from the fact that the causative agent(s) of this syndrome is still obscure, although there is now strong evidence that the etiologic agent may be a lymphocytotropic retrovirus called LAV (lymphadenopathy-associated virus) ${ }^{6}$ or HTLV-III (Human T-cell lymphocytotropic virus III) ${ }^{7}$ or more recently Human Immunodeficiency Virus (HIV). The high mortality rate associated with this disease has been an important factor that has escalated tension and fear about the spread of the AIDS syndrome.

AIDS is a distinctive disease of the immune system, and a number of immunologic abnormalities have been described. There is a remarkable lymphopenia (T-lymphopenia). Characteristically it is cells of the T-helper phenotype ( $\mathrm{Th}: \mathrm{OKT}_{4}$, Leu 3a) that are specifically depleted. Cells of the T 'suppressor/cytotoxic' phenotype (TS: $\mathrm{OKT}_{8}$, Leu 2) are not changed. These changes have stimulated most workers to concentrate on the decreased or reversed $\mathrm{T}$ helper/Tsuppressor ( $\mathrm{Th} / \mathrm{Ts}$ ) ratio as being an important marker for this syndrome. In addition to these alternations in T-cells subsets, assays of T-cell function in vitro using mixed cell populations obtained from patients with AIDS show decreased transformation responses to antigens and mitogens. These broadly match the altered representation of lymphocyte subpopulations. ${ }^{s}$

Delayed type cutaneous hypersensitivity responses to recall antigens are defective. This finding has been confirmed by various workers. Anergy in AIDS may 
reflect a failure of T-cells involved in delayed type hypersensitivity responses, in T-memory cells or in co-operation with macrophages.

Initially the humoral immunity in AIDS was thought to be intact, however, it has been demonstrated that there is a polyclonal B cell activation with failure to respond to neoantigens. ${ }^{8}$

Several other abnormalities of the immune system have been associated with AIDS e.g. defective natural killer (NK) cell function, 9,10 and defective monocyte functions (i.e. random migration, chemotaxis and phagocytosis). ${ }^{11,12}$

Prophet Mohammad (PBUH) said...

"...Whenever adultery and homosexuality appear in a society and people make them public (and become acceptable), plague and other diseases which were not previously known to their predecessors will appear and spread among them..."

In this Hadith the term "Fãhisha" was used to signify both homosexuality and illegitimate sexual relationships between a man and a woman i.e. adultery. Both of these have become prevalent and accepted practices among different age groups and social classes in various parts of the world. As a result of this sexual permissiveness, it is not surprising to find a high incidence of serious sexually transmitted diseases in these societies. The appearance of the new syndrome, AIDS, mainly transmitted by sexual contact (in particular, homosexual activity) is a good example of these serious sexually transmitted diseases. It is important to note here that the Hadith did not only mention the spread of Fāhisha, but also emphasized the fact that societies can go too far in their permissive attitude to the extent that they make it public and accept the Fāhisha as normal sexual relationships. The situation within some modern permissive societies, is very similar to the one described in the above cited Hadith with regards to both the spread and publicity of the Fāhisha in its broad sense i.e., adultery and homosexuality.

According to the Hadith there is a clear warning that if Fāhisha becomes spread in a society and reaches a high level then plague or plague-like diseases could spread. Literally the word plague in Arabic can be used to signify any serious epidemic form of disease.

With the present knowledge about the epidemiology of AIDS, it can be easily considered as a form of a serious epidemic disease. There is no doubt that today the world is facing a serious epidemic of AIDS in which the person-to-person spread is most important. Furthermore this syndrome is associated with a very high mortality rate, probably one of the highest mortality rates ever associated with a single infectious disease. It is not surprising that the term "Gays' plague" has emerged among the lay people in the U.S.A. as a term for AIDS.

The recent description of this syndrome as a consequence of a level of sexual permissiveness which was not known to previous conservative generations is another confirmation of what has already been mentioned in the Hadith that the spread of the Fãhisha will ultimately lead to the appearance of serious diseases which were unknown to the previous generations.

In another Hadith the prophet Mohammad (PBUH) said:

"...Whenever adultery becomes spread in a society death will increase...",13

The fact that AIDS is associated with a very high mortality rate confirms what was stated in the above mentioned Hadith. This high mortality rate reported with AIDS (over $80 \%$ two year mortality) reflects the irreversible immunodeficiency and the ultimate development of untreatable opportunistic infections and/or extensive tumor dissemination. It is worth mentioning here that for patients with opportunistic infections (with or without tumor development) the two year mortality is over $95 \%$ while it is much less for those with Kaposi's sarcoma alone i.e. about $50 \%$ two year mortality.

In addition to AIDS, other serious diseases are associated with the spread of adultery and homosexuality e.g. syphilis, cervical cancer, genital herpes, and B-hepatitis.

\section{Preventive measures against AIDS and similar diseases}

Islam has laid down very clear public health measures to prevent the appearance and spread of sexually transmitted diseases by stressing the importance of healthy and legitimate sexual relationships. Allāh says " ... Nor come nigh to adultery: For it is a shameful deed and an evil, opening the road to other evils", 14

Prophet Mohammad (PBUH) advised youth to get married when they have the means to do so and explained that one of the advantages of marriage is that it protects one from adultery and controls looking at the opposite sex.

Islam probibits not only adultery and homosexuality, but also any practice that stimulats the desire for committing adultery e.g. complete integration in life between males and females, the projection of women as sex symbols and drinking of alcohol.

The above mentioned verse "Nor come nigh to adultery" orders Muslims to avoid not only adultery, but it actually carries a much wider prohibition. Muslims should also avoid the ways and means which will stimulate the desire to indulge in illegitimate sexual reltionships. 


\section{References}

1. Sunan Ibn Maja, Book of Tumult (Bab Al-Fitan), No.22, Publisher, Eisa Al-Babi-AlHalaby, Vol. 2, p 1333.

2. Centers for Disease Control. Pneumocystis pneumonia, Los Angeles, Morbid Mortal Weekly Rep 1981;30:250.

3. Centers for Disease Control. Kaposi's sarcoma and pneumocystis pneumonia among homosexual men - New York City and California. Morbid Mortal Weekly Rep 1981;30:305.

4. Curran JW, AIDS - two years later.

NEJM 1983;309:609.

5. Harris C, Butkus S C, Klein RS et al. Immunodeficiency in female sexual partners of men with the acquired immunodeficiency syndrome. NEJM 1983;308:1181.

6. Barre-Sinoussi F, Chermann JC, Rey F et al. Isolation of $\mathrm{T}$ lymphotrophic retrovirus from a patient at risk for acquired immune deficiency syndrome (AIDS) Science 1983;220:868.

7. Popovic M. Sarngadharan MG, Read E, Gallo $\mathrm{RC}$. Detection, isolation, and continuous production of cytopathic retroviruses (HTLV-III) from patients with AIDS and pre-AIDS. Science
$1984 ; 224: 497$.

8. Pinching AJ. The Acquired Immune Deficiency Syndrome. Clin Exp Immunol 1984;56:1.

9. Siegal FP, Lopez C, Hammer GS, Brown AE, et al. Severe Acquired Immunodeficiency in male homosexuals manifested by chronic perianal ulcerative Herpes simplex lesions. NEJM 1981;305:1439.

10. Poon MC, Landy A, Prasthoffer EF, Stagno S. Acquired Immunodeficiency Syndrome with Pneumocystis carinii pneumonia and Mycobacterium airum intracellular infection in a previously healthy patient with classic hemophilia. Ann Int Med 1983;98:287.

11. Maurice PDL, Smith NP, Pinching AJ. Kaposi's sarcoma with benign course in a homosexual.Lancet 1982;1:571.

12. Pinching AJ, McManus TJ, Jeffries DJ, et al . Studies of cellular immunity in male homosexuals in London. Lancet 1983;11

13. Imam Malik's Al-M'watta', Book of Jiḥad, No.26, Diwan Press, p 202.

14. Glorious Qur'ān, Chapter 17, verse 32.

15. Sahih Muslim (Abridged), Book of Marriage, No.794, Al-Maktab Al-Islami 1977, p 207. 